Hidayat, dkk. Jurnal Pendas Mahakam. Vol 5 (2). 106-111. Desember 2020

\title{
PENGEMBANGAN BAHAN AJAR BERBASIS PROBLEM BASED LEARNIG (PBL) MATA PELAJARAN IPA PADA TEMA LINGKUNGAN SAHABAT KITA SISWA KELAS V SEKOLAH DASAR
}

\author{
Hidayat, Muhammad Amir, Herliani \\ Universitas Mulawarman \\ hidayat3a@gmail.com
}

\begin{abstract}
The main objective of Problem Based Learning (PBL) is the ability to think critical and problem solving skills while developing learners 'ability to actively build their own knowledge. The PBL is also intended to develop the independence of learning and the social skills of learners that are formed when they work to identify relevant information, strategies, and learning resources to resolve problems. The research method used is research and Development to produce a specific product, and to test the effectiveness of the product. Research and Development aims to improve the quality of education and develop and validate the outcomes of education. The study obtained pre-test and post-test value data which will be carried out by the process of data processing using SPSS 2.4 i.e. the T test in pairs (Paired-Samples T Test) was obtained that the average value of Pre-Test 68.4 and the average Post-Test value of 87.8. Number of 15 students. Deviation Freedom 14 value sig. 2 tailled 0.000 with a degree of confidence 95\%. Where the lowest grade pre-test students are 60 and the highest 75 while the lowest post-test students are 85 and the highest 93. Based on the results it shows that the grades of students increased by $19.4 \%$ or 291 points. It can be said that the PBL model SCIENCE subject reference book developed can improve student learning outcomes.

Kata kunci: Problem Based Learning, reseach and development
\end{abstract}

\section{PENDAHULUAN}

Menurut Trianto (2010) dijelaskan bahwa proses pembelajaran hingga dewasa ini masih memberikan dominasi guru dan tidak memberikan akses bagi peserta didik untuk berkembang secara mandiri melalui penemuan dalam proses berpikirnya. Menurut Gray (2011) setiap pendidikan seharusnya mengalami inovasi baru yang dirancang untuk mengajarkan keterampilan khusus, keyakinan dan konsep untuk menjadi lebih baik. Kurikulum 2013 menekankan pada penilaian kinerja untuk mengetahuai pencapaian kompetensi peserta didik yang meliputi pengetahuan, keterampilan dan sikap, fokus penilaian pendidikan adalah keberhasilan belajar peserta didik untuk mencapai kompetensi yang ditentukan dalam hal ini guru dapat memperkaya ide dan gagasan guna membantu mengoptimalkan kemampuan berpikir peserta didik. Kendala yang dihadapi guru tidak hanya sebatas menyusun rencana pelaksanaan pembelajaran (RPP) dan penilaian kognitif, afektif dan psikomotorik tetapi juga terkendala dalam guru kurang memahami dalam 
menyusun sintaks pembelajaran hingga rubrik penilaian dalam pembelajaran tentu siswa. pemecahan masalah masalah pembelajaran diatas adalah dengan memiliki model-model pembelajaran yang inovatif dan kreatif, adapun model yang bisa digunakan adalah model problem based learning yang merupakan pembelajaran inovatif yang paling signifikan, mengembangkan keterampilan sepanjang hayat dengan pola pikir yang terbuka, refleksi, kritis dan dapat meningkatkan keaktifan peserta didik. pembelajaran berbasis masalah menuntut siswa untuk melakukan suatu kerja ilmiah dan menyusun sebuah laporan, sehingga pembelajaran ini memberi kesempatan pada siswa untuk dapat meningkatkan keterampilan proses sainsnya (Rahayu 2012). Fungsi bahan ajar model Problem Based Learning mempunyai fungsi:

a) Mengetahui gambaran tentang desain pembelajaran dengan menggunakan model problem based learning di kelas V Sekolah Dasar Sangatta Selatan pada pelajaran IPA dalam tema Lingkungan Sahabat Kita.

b) Menganalisis kelayakan enerapan bahan ajar berbasis problem based learning di kelas V Sekolah Dasar Sangatta Selatan pada pelajaran IPA dalam tema Lingkungan Sahabat Kita.

c) Menganalisis efektivitas bahan ajar Mata Pelajaran IPA Pada Tema Lingkungan Sahabat Kita Siswa Kelas V Sekolah Dasar berbasis problem based learning .

\section{METODE PENELITIAN}

Penelitian ini bertujuan untuk mengembangkan model pembelaja ran berbasis Problem Based Learnig (PBL) mata pelajaran IPA pada tema lingkungan sahabat kita siswa kelas V. Prosedur pengembangan yang akan dilakukan peneliti mangacu pada 10 langkah pengembangan yang dikembangkan oleh Borg \& Gall yang terdapat sepuluh tahap proses pengembangan:

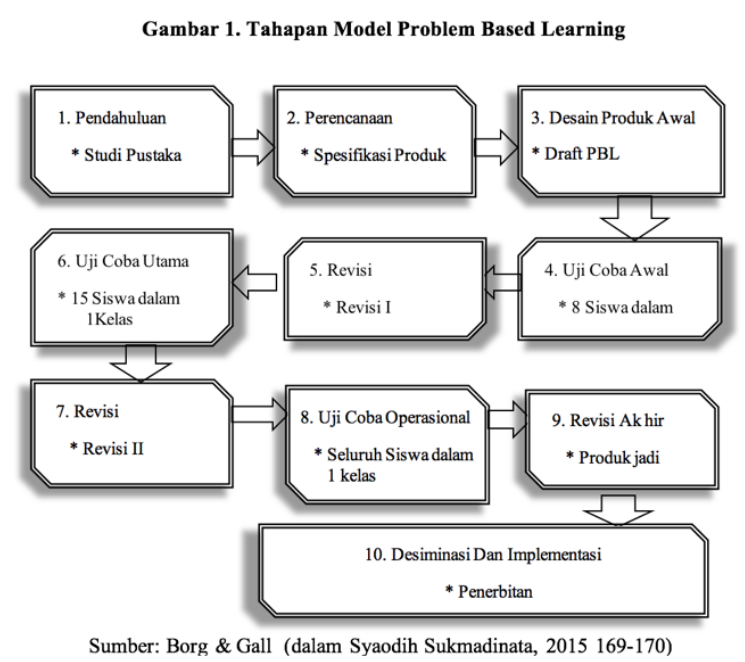

Penelitian dan pengumpulan data (research and information collecting)

1. Perencanaan (planning)

2. Pengembangan draf produk (develop preliminary form of product)

3. Uji coba lapangan awal (premilinary field testing)

4. Merevisi hasil uji coba(main product revision)

5. Uji coba lapangan utama(main field testing)

6. Penyempurnaan produk hasil uji coba lapangan (operasional product revision) 
7. Uji coba lapangan operasional(operasional field testing)

8. Penyempurnaan produk akhir (final product revision)

9. Diseminasi dan implementasi (dissemination and implementation)

\section{A. Uji Pengembangan}

1. Uji coba produk terbatas

Dalam uji coba ini akan menghasilkan nilai capaian pre-test (sebelum) dan post-test (sesudah) akan dianalisis untuk mengetahui perbedaan hasil belajar sebelum dan setelah menggunakan bahan ajar berbasis model PBL pada mata pelajaran tematik.

\section{Uji Coba Soal}

Sebelum diuji cobakan ke siswa dalam seting eksperimen, instrument tes kognitif diuji cobakan terlebih dahulu (try out). Data yang diperoleh kemudian dianalisis untuk mengetahui validitas, reliabilitas, daya pembeda, dan tingkat kesukaran soal.

\section{Uji Lapangan Operasional}

Tujuan dari uji lapangan operasional yang dilakukan adalah untuk mengetahui efektivitas produk berupa rancangan bahan ajar Problem Based Learning yang dibuat. Uji lapangan skala kelompok kecil dengan jumlah 8 siswa dan Uji lapangan kelompok besar dengan jumlah 15 siswa.

dengan metode pretest dan postest pembelajaran model Problem Based Learning siswa SDN 004
Sangatta Selatan. Desain yang digunakan dalam penelitian ini adalah: One group Pretest-postest.

\section{$\mathrm{O} 1 \mathrm{X} \mathrm{O} 2$}

Keterangan:

O1 = Nilai Pre test(sebelum diberi perlakuan)

$\mathrm{O} 2$ = Nilai Post test kelas (setelah diberi perlakuan)

Data yang akan diambil dalam tahap uji lapangan operasional adalah sebagai berikut:

a. Data hasil penilaian pengetahuan yang diperoleh dari hasil pretest dan postest

b. Data hasil penilaian keterampilan,

c. Data hasil penilaian sikap yang diperoleh dari hasil angket pretest dan postest serta penilaian antar teman,

d. Data keterlaksanaan model pembelajaran,

e. Data angket kelayakan.

\section{B. Teknik Analisis Data}

Teknik analisis data kuantitatif dalam penelitian ini menggunakan analisis statistik deskriptif, yang berupa pernyataan sangat kurang, kurang, cukup baik, baik, sangat baik, yang diubah menjadi data kuantitatif dengan skala 5 yaitu dengan penskoran dari angka 1 sampai dengan 5. Sugiyono $(2013 ; 132)$ menyatakan bahwa pengukuran variabel dengan skala ordinal menggunakan instrumen skala Likert. 


\section{Waktu Dan Tempat Penelitian}

Penelitian ini telah dilaksanakan pada: 13 Januari 2020 semester genap tahun ajaran 2019/2020 di SD Negeri 004 Sangatta Selatan.

\section{Waktu Dan Pelaksanaan Desiminasi}

Langkah terakhir dari 10 tahapan menurut Borg and Gall, Desiminasi yang dilaksanakan pada Kelompok Kerja Guru (KKG) Gugus I Sekolah Dasar Wilayah Kecamatan Sangatta selatan. Pelaksanan dilaksanakan pada Sabtu, 8 Februari 2020 di SDN 004 Sangatta Selatan

\section{E. Subjek Penelitian}

\section{Uji Coba Awal (Validasi Ahli)}

Tahap ini subyek uji coba dilakukan oleh tiga orang ahli yaitu ahli materi, ahli pembelajaran biologi dan ahli desain modul serta dua orang guru sebagai praktisi.

\section{Uji Coba Lapangan Utama Skala Terbatas}

(Uji Kelompok Kecil)

Subyek dalam uji coba kelompok kecil adalah delapan siswa kelas V SDN 004 Sangatta Selatan (selain responden yang digunakan untuk uji lapangan operasional).

\section{Uji Lapangan Operasional}

Subyek dalam uji lapangan operasional adalah seluruh kelas V SDN 004 Sangatta Selatan. Populasi dalam uji lapangan operasional adalah semua siswa kelas V SDN 004 Sangatta Selatan. Responden dalam uji lapangan operasional adalah satu kelas untuk kelas eksperimen yang dipilih secara langsung.

\section{HASIL PENELITIAN DAN PEMBAHASAN}

1. Produk dari hasil pengembangan di desain sebagai bahan ajar berupa buku referensi yang merupakan media pembelajaran guru dan siswa. Didalamnya terdiri dari materi yang berhubungan dengan pelajaran tematik. Bahan ajar ini telah dilakukan dan dipraktikkan di kelas V SDN 004 Sangatta Selatan. Pendekatan saintifik yaitu ciri khas produk ini. Yaitu: memahami berbagai materi menggunakan pendekatan ilmiah, bahwa informasi bisa berasal dari mana saja, kapan saja, tidak bergantung pada informasi searah dari guru. Pendekatan saintifik terdiri lima langkah. Langkah tersebut biasa disingkat $5 \mathrm{M}$, yaitu:

a) Mengamati,

b) Menanya,

c) Mengumpulkan informasi,

d) Mengasosiasi,dan

e) Mengomunikasikan

melalui penambahan media praktikum berupa pembelajaran interaktif. Sehingga memotivasi siswa untuk lebih semangat belajar untuk meningkatkan prestasinya. Sedangkan format media belajarnya berupa mater-materi yang dikembangkan dengan KI dan KD pada Tema pembelajaran Lingkungan Sahabat Kita yang disesuaikan dengan pengembangan proses berfikir siswa. Dalam pemanfaatan bahan ajar menggunakan model PBL(Problem Based Learning) ini guru berperan sebagai fasilitator, dimana guru menyampaikan materi pelajaran melalui bahan ajar tersebut kemudian siswa 
meresponnya dengan cara melihat, mendengar dan menjawab soal-soal yang ditanyakan melalui Produk Bahan Ajar.

2. Dari penilaian tersebut dapat diketahui kelayakan hasil pengembangan bahan ajar yang digunakan oleh guru dalam pembelajaran tematik. Pengembangan bahan ajar ini telah divalidasi oleh ahli materi, ahli desain pembelajaran dan guru mata pelajaran, sehingga layak dan dapat digunakan oleh guru dan siswa. Hal ini membuktikan bahwa bahan ajar menggunakan model PBL ini sudah layak untuk digunakan dalam penyampaian materi pembelajaran tematik.

3. Proses kegiatan belajar mengajar pada hakekatnya adalah untuk mengembangkan aktivitas dan kreativitas peserta didik, melalui berbagai interaksi aktif dan pengalaman belajar. Memperhatikan aktivitas dan kreativitas peserta didik ini merupakan point penting bagi seorang guru, karena nantinya akan mempengaruhi keberhasilan pembel

ajaran di kelas. Implementasi bahan ajar menggunakan model PBL dalam pembelajaran tematik di kelas V SDN 004 Sangatta Selatan membutuhkan keuletan dan perkembangan usia peserta didik.

Adapun data uji coba yang dilakukan pada siswa kelas 5 SDN 004 Sangatta Selatan ini menunjukkan nilai terendah pre-test siswa adalah 60 dan nilai tertinggi adalah 75 . Sedangkan nilai terendah dari hasil post-test siswa adalah 85 dan nilai tertinggi adalah 93 .
Sehingga hasil uji test tersebut menunjukkan bahwa pemanfaatan bahan ajar mengguna kan model Problem Based Learning.

\section{KESIMPULAN}

Dalam Pengembangan Bahan Ajar Berbasis PBL (Problem Based Learning) Mata Pelajaran IPA Tema 8 Lingkungan Sahabat Kita Kelas V SDN 004 Sangatta Selatan diperoleh kesimpulan sebagai berikut:

1. Bahan ajar menggunakan model PBL(Problem Based Learning) ini, guru berperan sebagai fasilitator, menyampaikan materi melalui bahan ajar tersebut kemudian siswa merespon dengan cara melihat, mendengar dan menjawab soal-soal yang ditanyakan melalui Produk Bahan Ajar. Sehingga praktis diguna

kan siswa dalam pembelajaran.

2. Bahan ajar berbasis ploblem based learning, Mata Pelajaran IPA Tema 8 Lingkungan Sahabat Kita Kelas V mendukung materi pembela jaran IPA valid dari aspek materi dan media dengan kriteria sangat baik, baik dari aspek materi maupun media berdasarkan penilaian para ahli.

3. Bahan ajar berbasis ploblem based learning, Mata Pelajaran IPA Tema 8 Lingkungan Sahabat Kita Kelas V mendukung materi pembela jaran IPA efektif dalam meningkatkan hasil belajar siswa. Hal ini terlihat dari peningkatan nilai yang tinggi dan hasil uji t yang menunjukkan bahan ajar efektif digunakan. 


\section{DAFTAR PUSTAKA}

Abidin, Yunus. 2014. Desain Sistem Pembelajaran dalam Konteks Kurikulum 2013.

PT Refika aditama: Bandung

Ahlam, EL-Shaer and Hala Gaber 2014 "Impact of Problem-Based Learning on Students Critical Thinking Dispositions, Knowledge Acquisition and Retention". Journal of Education and Practice

Alesandrini, K. \& Larson, L. 2002. Teachers bridge to constructivism. The Clearing House, Vol. 2. No. 2 Hal 119-175.

Arends, R. (2008). Learning to teach : Belajar untuk mengajar. Jogjakarta: Pustaka Pelajar.

Bafadal, I. (2013). Panduan Teknis Pembelajaran Tematik Terpadu Dengan Pendekatan Saintifik. Jakarta: Kemendikbud Dirjen Dikdas Direktorat Pembinaan Sekolah Dasar.
Hadist Awalia Fauzia. 2018. Penerapan Model Pembelajaran Problem Based Learning Untuk Meningkatkan Hasil Belajar Matematika SD. Jurnal Primary Program Studi Pendidikan Guru Sekolah Dasar Fakultas Keguruan dan Ilmu Pendidikan. Universitas Riau.

Trianto. (2010). Mendesain Model Pembelajaran Inovatif-Progresif Konsep, Landasan, dan Implementasinya pada Kurikulum Tingkat Satuan Pendidikan (KTSP). Jakarta: Kencana.

Rusman. (2011). Model-Model Pembelajaran: Mengembangkan Profesionalisme. Jakarta: Rajawali Press. 